\title{
Effects of Bamboo Neck Lymph Drainage on Facial Edema and Skin Condition
}

Mi Young Lee, Yun Kyoung Oh*

Department of Cosmetology, Changshin University, Changwon-si, Gyeongsangnam-do, Korea

\author{
*Corresponding author: Yun-Kyoung \\ Oh, Department of Cosmetology, \\ Changshin University, 262 Palyongro, \\ MasanHoewongu, Changwon-si, \\ Gyeongsangnam-do 51352, Korea \\ Tel.: +82552501212 \\ Fax: +82552501215 \\ Email: yk212@cs.ac.kr
}

Received April 28, 2020 Revised May 22, 2020

Accepted June 05, 2020

Published June 30, 2020

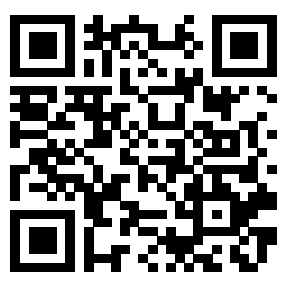

\begin{abstract}
Purpose: The purposes of this study were to perform bamboo lymph drainage, reflected with the principles of a brain lymph system, and the doctor border type lymph drainage on the neck area and to compare the effects of each on facial edema and skin condition. Methods: Female undergraduate students in the 20 s were recruited in Daegu; from these 20 were selected. The experimental group subjects underwent lymph drainage using bamboo on the neck area for 30 minutes while the control group underwent hand lymph drainage in the same manner twice a week for 3 weeks. Results: First, as a result of the changes in facial edema status according to the BLD and MLD, the jaw angle increased significantly after 3 times and after 6 times, and the circumference of the jaw and neck were significantly decreased. Second, an understanding of the changes in the facial skin condition according to the BLD and MLD enabled considerable reduction in facial wrinkles, epidermal pigmentation, and skin tone after 3 treatment sessions than that before the treatments and gradually decreased after 6 treatment sessions. Third, the changes in facial edema and skin condition as per the BLD and MLD were not different between the two groups. Fourth, the subjective evaluation of the subjects showed that the satisfaction of the management subjects was very high. Conclusion: The bamboo lymph drainage could be a solution for reducing the physical fatigue of a therapist while effectively managing the variance among therapists, depending on individual's skill and experience.
\end{abstract}

Keywords: Bamboo lymph drainage, Manual lymph drainage, Bamboo, Lymph drainage, Neck and edema

\section{Introduction}

현대 사회는 본능적으로 개인의 외모에 대한 행동양식의 하나로 이상적인 신체 이미지 가꾸기를 추구해왔으며, 동서양을 막론하고 시대에 따라 미인상은 변화되어가고 미의 표현 양식의 기준은 시대 적, 사회적, 문화적으로 다양하게 변화되어 표현된다는 특성을 가진 다(Lee, 2014). 얼굴은 커뮤니케이션의 중요한 역할로 삶의 방식까 지 표현되어 대인관계에 영향을 미치기도 한다(Kwon \& Heo, 2019). 현대는 대중매체(mass media)가 발달하면서 이상적인 외모기준으로 작고 또렷한 서구적 얼굴형을 선호하게 되면서 안면의 성형수술 및 시술이 보편화되었다. 2014년 국제미용성형수술 협회(international society of aesthetic plastic surgery, ISAPS) 조사결과에 따르면 한 국의 성형(수술, 의료시술 포함) 건수가 나라별 순위에서 4 위에 랭크
되었다. 사회적 추세나 변화된 욕구에 성형수술에 대한 인식을 긍정 적으로 받아들이는 20-30대 여성들에게 외모관리는 경쟁력의 필수 요소가 되고 개인의 자신감과 내적 자신감에 영향을 줄 수 있어 미용 성형수술이 증가하고 있다. 하지만 안면미용 성형수술 후 나타나는 부종, 통증, 멍 등의 부작용으로 심한 불안감과 생리적인 변화를 초 래하여 회복에 부정적인 영향을 주게 되었다(Min \& Kim, 2010).

피부미용 분야에서 부종 감소를 위한 효과적인 관리방법으로 림 프드레나지가 관심을 받아왔으며 그 효과가 입증되어왔다(Min \& Kim, 2010; Han, 2005; Sim, 2006). 이러한 연구들은 부종감소를 위해 얼굴 부분과 앞 목, 옆 목을 주로 닥터보더식 기법(Wittlinger \& Wittlinger, 2003)으로 관리하였으며 목 림프절 부위인 프로펀더스 (profundus), 미들(middle), 터미누스(terminus)에 주로 관리를 하였 다. 

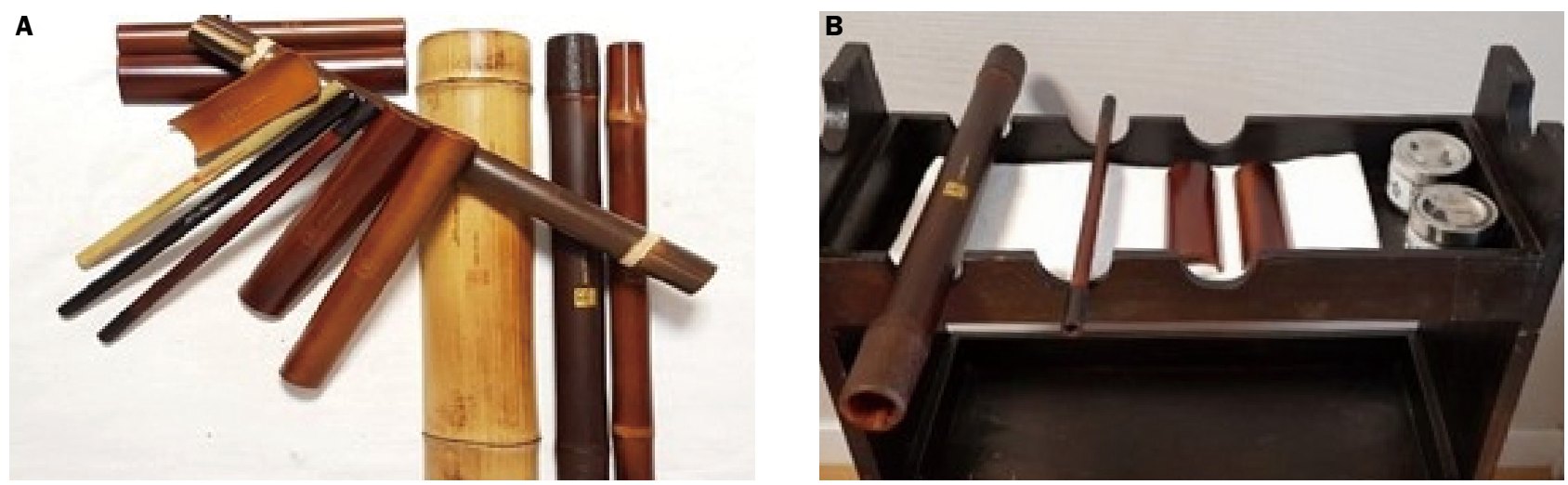

Figure 1. Bamboo lymph drainage research tool.

(A) It is a bamboo used in the bamboo lymph drainage designed by this researcher and manufactured by anima bamboo. (B) Dark red bamboo (diameter $1.5 \mathrm{~cm}$, length $35 \mathrm{~cm}$ ) and small bamboo (diameter $6 \mathrm{~cm}$, length $15 \mathrm{~cm}$ ) were used.

최근 발견된 뇌 림프시스템의 독소 배출 통로가 뒷목 부위의 깊은 림프관(Iiff et al., 2012)이라는 사실에 비춰볼 때 안면 림프드레나지 에서 뒷목 관리가 중요하다는 것을 알 수 있다. Yoon \& Choi (2012) 는 안면 부위에 림프드레나지로 심장과 뇌기능에 미치는 전기신경 생리학적 영향에 대해 연구하였고, 자율신경이 안정되고 깊은 잠을 잘 때 뇌 림프계가 활성화되어 목 부위 림프관으로 연결된다는 연구 (Xie et al., 2013)는 목 림프 순환이 뇌 림프순환에 영향을 미친다고 할 수 있다. 2012년 미국 로체스터 의과대학 연구진이 쥐 실험을 통 해 뇌에도 림프관이 있다는 것을 발견하고 글림프시스템(glymphatic system)'으로 명명하였다. 이와 같은 연구는 뇌림프, 즉 글림프시스 템(glymphatic system)의 원리(Wang et al., 2018)를 반영한 목 부위 관리를 통하여 안면의 순환을 촉진시킬 수 있고 안면 부종의 효과가 있음을 시사한다.

안면성형 수술 및 시술로 부종이 있거나 멍이 든 고객은 안면에 직 접적인 관리가 심리적 부담이나 통증, 감염의 불안감을 들게 할 수 있 다. 반면 바로 누운 상태(supine position)에서 시술되는 목 부위 뱀부 림프드레나지는 테라피용 뱀부(대나무)를 사용하여 안면 부위 접촉이 회피될 수 있고 테라피용 대나무가 관리자의 손보다 공간을 작게 차 지하여 뒷목 관리와 같이 좁은 공간에서 효율적으로 활용할 수 있다. 또한 뱀부 본연의 차가운 성질은 미세 염증 및 부종, 통증 개선에 도 움을 줄 수 있다. 뱀부 림프드레나지(bamboo lymph drainage, BLD) 는 뱀부테라피와 림프드레나지가 합쳐진 말로써 피부미용기술의 하 나이며 비압박식 테크닉으로 압력을 가하지 않고 인체의 건강에 도움 이 되는 미용적 효과기술을 의미한다. 뱀부테라피는 기원과 사용법, 대나무 도구의 형태에 따라 크게 압박식과 비압박식, 두 가지로 나누 어진다. 주로 근육에 강한 압력을 가하기 위해 사용되는 괄사기법인 압박식은 미국, 유럽과 동남아에서 기원하였는데 보통 일반 대나무를 그대로 사용한다. 반면 비압박식으로 사용되는 테라피기법은 한국 선 조의 정서적, 문학적, 철학적 정신을 바탕으로 제작되어 한국전통 기 법인 옷칠예를 적용하여 양쪽에 손잡이가 있는 대나무를 사용하는 것
이 특징이다(Lee, 2016).

뱀부 림프드레나지는 대나무의 둥근 표면과 길이를 이용하여 피부 감각 수용체 및 림프표재, 림프심부를 자극함으로써 자율신경을 안정 시키고 호르몬 균형을 도모하는 심신면역 강화기법으로 글림프시스 템을 통해 청소된 노폐물과 독소들이 목 부위 림프관으로 배출된다. 목 뱀부 림프드레나지 효과는 뇌척수액의 흐름을 촉진하며 스트레스 로 인한 교감신경을 흥분억제하고 뇌파를 안정시키는 내적효과와, 림 프표재, 심부 림프액 흐름촉진, 면역기능을 높여 원활한 독소배출에 작용한다(Lee, 2016). 또한 자율신경의 안정으로 심리적·정신적 상태 의 균형을 유지시킨다(Lee, 2016; Son et al,. 2019).

지금까지 림프관리와 관련하여 스트레스 관련 연구와(Pyun \& Yun, 2014; Song, 2019), 자율신경과 부종관련 연구(Eum et al., 2017; Kim et al., 2007; Kim \& Ro, 2009; Sim, 2006) 등이 활발히 이루어지고 있다. 그러나 뱀부테라피(Osorio, 2008)와 관련된 선행연 구는 매우 부족한 실정이고, 특히 목에 적용한 뱀부테라피 연구는 전 무하다. 그런데 글림프시스템(glymphatic system)의 원리를 반영하 여 뒷목부위를 집중적으로 관리하는 목 부위 뱀부 림프드레나지는 안 면 부종과 피부상태 변화에 효과 있을 것으로 생각되며 이와 관련된 실질적인 연구가 요구된다.

따라서 이 연구는 목 부위에 뇌 림프시스템 원리를 반영한 뱀부 림 프드레나지(BLD)와 닥터보더식 수기 림프드레나지(manual lymph drainage, MLD)를 실시하여 안면부종과 피부상태의 변화를 비교 분 석함으로써 뱀부 림프드레나지 활용에 대한 기초자료를 제시하고자 한다.

\section{Methods}

\section{1. 연구 설계}

목 부위에 뱀부와 수기를 활용한 림프드레나지를 실시하고 안면부 

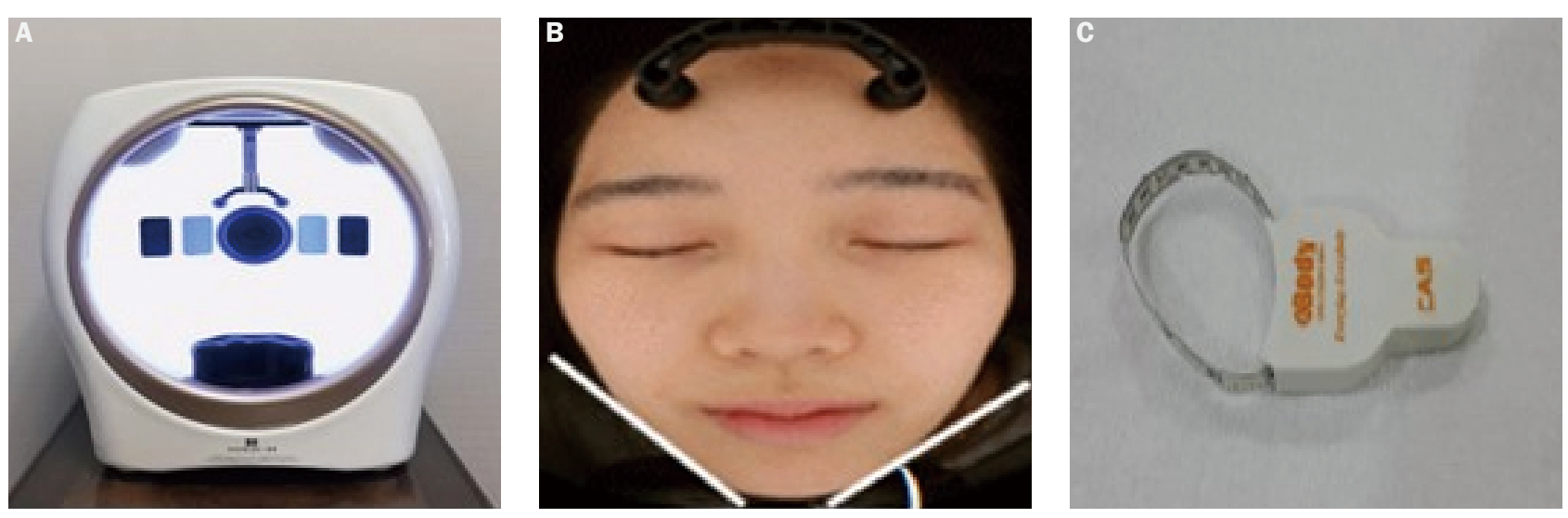

Figure 2. Skin analyzer and tape measure for measuring the circumference.

(A) Skin analyzer (JANUS III; PIE Co., Ltd, Korea). With our skin-analyzing device, we take pictures of your face with natural light, polarized light, and ultraviolet light to analyze pores, wrinkles, pigmentation, skin color, and skin tone; (B) Jaw Angle measurement; (C) Tape measure for circumference.

종 및 피부상태 차이를 알아보기 위하여, 대구지역에 거주하는 20대 여대생을 대상으로 SNS을 통해 모집광고를 실시하였다. 연구 참여 를 희망하는 지원자는 연구자와 $1: 1$ 개별 면담을 실시하였고 연구의 목적을 이해하고 자발적으로 연구의 참여에 동의(참여동의서 작성)한 지원자 중 20 명을 선정하였다. 연구대상자 20 명 중 뱀부 림프드레나 지(BLD) 10 명, 수기 림프드레나지(MLD) 10명을 무작위로 선정하고 각각 주 2 회씩 총 6 회의 관리를 3 주간 실시하였다. 대상자는 사전, 3 회 관리 후, 6 회 관리 후 피부 상태 및 안면 둘레를 측정하였으며 6 회 관리 후 설문지를 통해 관리에 대한 주관적 평가를 실시하였다. 실험 은 대구에 소재한 A에스테틱에서 2019년 4월 18일부터 5월 17일까 지 실시되었다.

\section{2. 관리기법}

뱀부 림프드레나지(BLD) 기법은 아니마뱀부테라피 개발자로 실무 경력 20년 이상의 전문가인 연구자가 매뉴얼을 개발하여 실시하였고, 수기 림프드레나지(MLD)는 닥터보더식으로 동일한 연구자가 실시하 였다. 관리 순서는 두 집단 모두 동일하며 뱀부 림프드레나지(BLD)는 뱀부를 사용하고, 수기 림프드레나지(MLD)는 관리자의 손으로만 실 시하였다. 뱀부 림프드레나지 관리 기법중 폴스피싱(force fishing, 평 형낚기)는 평형방향의 일정한 힘으로 시작과 끝의 힘이 변형이 없이 피부피막 까지만 적용되는 압력을 사용하여 압박된 근육층의 주변공 간을 확보하여 과긴장된 신경을 이완하는 것이 목적이다. 폴스피싱는 뱀부전체길이의 $2 / 3$ 이상을 사용하여 한 동작이 최소 $5 \mathrm{~s}$ 이상 유지 하여 피부 감각수용체를 부드럽게 자극하여 자율신경계의 안정화를 유도하여 림프순환을 배가시킨다. 폴스피싱이 잘 적용된 후 근육이완 에 적용되는 넷기법(net fishing)을 약한 압력으로 부드럽게 실시하였 다. 대상자 모두 동일한 제품으로 자가 클렌징을 한 후, 림프드레나지 (30 min), 마무리(5 min) 단계로 총 $35 \mathrm{~min}$ 간 진행하였다(Table 1).

\section{3. 연구도구}

1) 뱀부

뱀부 림프드레나지에 사용된 뱀부로 본 연구자가 고안하여 아니 마뱀부에서 제작된 것으로 '다크레드 뱀부'(지름 $1.5 \mathrm{~cm}$, 길이 35 $\mathrm{cm}$ )와 '스몰뱀부'(지름 $6 \mathrm{~cm}$, 길이 $15 \mathrm{~cm}$ )를 사용하였다(Figure 1).

\section{2) 안면 측정도구 및 측정방법}

안면 피부상태(안면 주름, 표피층 색소, 피부 톤)와 턱각도를 측정 하기 위하여 PIE사의 JANUS III 피부 분석기(JANUS III; PIE Co. Ltd, Korea)를 사용하였다(Figure 2). 대상자는 피부 분석기에 안 면 전체를 고정시키고 외부광원을 차단한 후 측정하였고 측정된 항 목은 digital data로 자동 저장되었다. 주름(wrinkles)은 일반광 비 추어 shadow method 측정법(Leem et al., 2020)으로 면적대비 측 정값이 클수록 안면 주름이 심하고, 표피층 색소(epidermal layer pigmentation)는 편광원을 비추어 측정값이 클수록 색소가 많음을 의미하며 피부 톤은 어둡다는 것을 뜻한다. 턱각도(jaw angle)는 양 쪽 볼 접선의 각도를 구하고, 목둘레(neck circumference)와 턱둘 레(chin circumference)의 측정도구로 한진코텍스줄자를 사용하였 는데 목둘레는 목앞점, 오른쪽 목옆점, 왼쪽 목옆점, 목뒤점을 지나 는 둘레로 측정하였고, 턱둘레는 왼쪽 귀밑에서 턱선라인을 지나 오 른쪽 귀밑까지 측정(사이즈코리아, 지식경제부 기술표준원기준)하 였다(Figure 2). 측정시기와 조건은 실내온도 $20-25^{\circ} \mathrm{C}$, 실내습도 40-70\%를 유지하였고, 관리 전 자가 클렌징을 실시하고 $30 \mathrm{~min}$ 경 과 후, 3 회 관리 후, 6 회 관리 후로 총 3 회 측정하였다.

\section{3) 주관적 평가 도구}

관리 후 대상자의 주관적 평가를 알아보기 위하여 선행연구(Lee \& Ryu, 2012; Min \& Kim, 2010)를 참고로 설문조사를 실시하였 다. 실험 후 만족도와 관련하여 관리부위의 편안함, 붓기 개선, 피부 


\section{Effects of Bamboo Neck Lympy Drainge}

안색 개선, 전반적인 만족도 4 문항을 5 점 리커트 척도로 구성하였 다.

\section{4. 자료분석방법}

본 연구에서는 SPSS 23.0을 활용하여 변인들에 대한 기초자료분 석으로 빈도 분석 및 기술통계분석을 실시하였다. 림프드레나지 개 입효과의 분석은 개입전의 실험군과 대조군에 대한 동질성검정을 위해 독립 $t$-검정을 실시하였고, 반복적인 개입에 대한 실험의 효과

Table 1. MLD and BLD management process

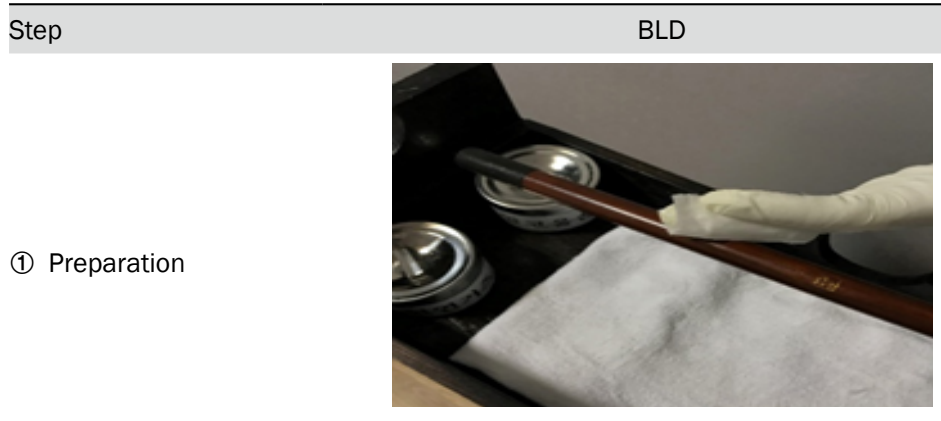

Hand \& Bamboo disinfection

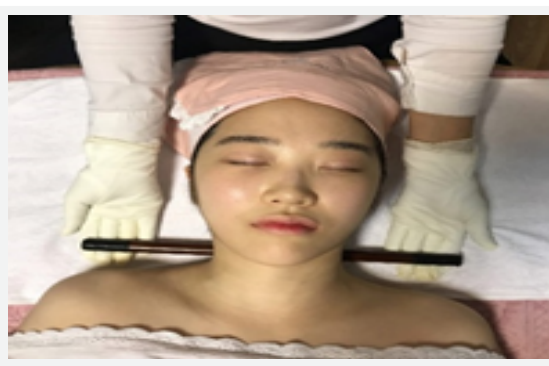

Cervical and occipital nodes $\rightarrow$ Supraclavicular Force fishing

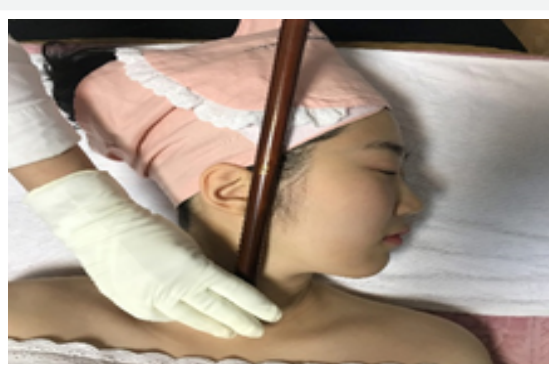

Lymph direction Parotis $\rightarrow$ Angulus $\rightarrow$ Profumdus $\rightarrow$ Terminus Force fishing and net fishing

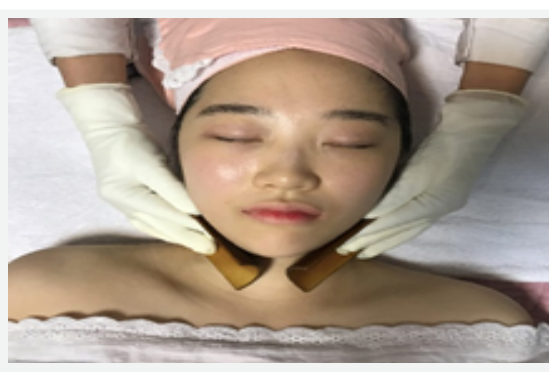

Lymph direction

Profundus $\rightarrow$ Middle $\rightarrow$ Terminus Pump technique $\rightarrow$ Infraclavicular

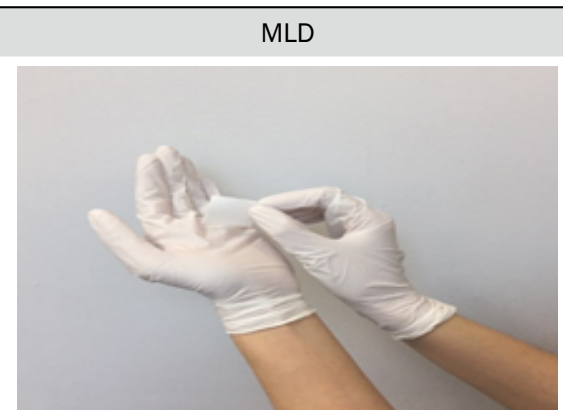

Hand disinfection

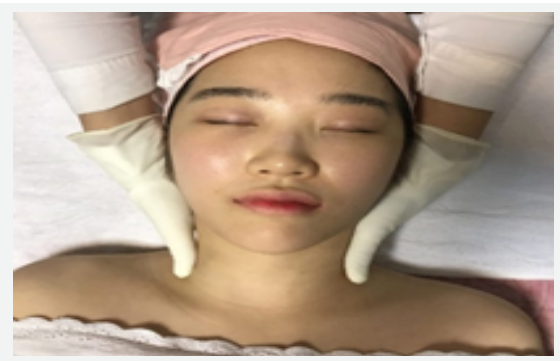

Cervical and occipital nodes $\rightarrow$ Supraclavicular Stationary circles

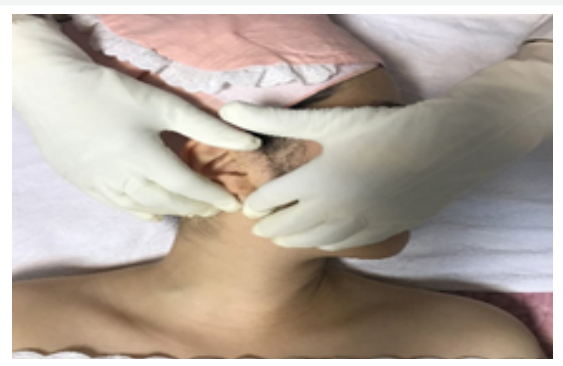

Lymph direction

Parotis $\rightarrow$ Angulus $\rightarrow$ Profumdus $\rightarrow$ Terminus Stationary circles

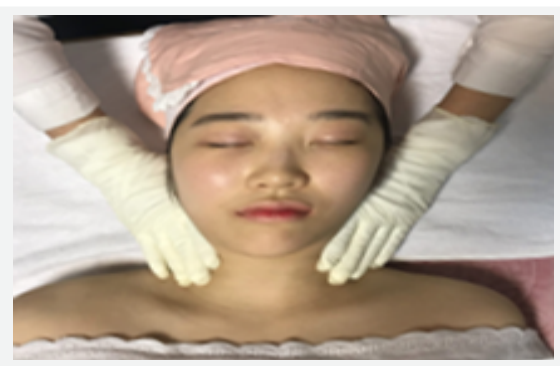

Lymph direction

Profundus $\rightarrow$ Middle $\rightarrow$ Terminus

Pump Technique $\rightarrow$ Infraclavicular 
는 반복측정 분산분석(repeated measure ANOVA)을 실시하였다. 모든 분석의 유의도 기준은 0.05 로 설정하였다.

\section{5. 동질성 검증}

실험대상자를 무작위로 할당하였지만, 관리 전에 집단들이 동일 한지를 검증하기 위하여 독립 $t$-검정을 실시하였으며, 그 결과 실험 전에 모든 집단은 측정항목에 대해서 동일한 분포를 형성하고 있는 것으로 확인되었다(Table 2).

\section{Results and Discussion}

\section{1. 안면 부종의 변화}

목 부위 뱀부 림프드레나지(BLD)와 수기 림프드레나지(MLD) 가 턱각도, 목둘레, 턱둘레의 변화에 미치는 영향을 알아보기 위하 여 림프드레나지를 6회 실시하고 뱀부 림프드레나지(BLD)군과 수 기 림프드레나지 $(\mathrm{MLD})$ 군의 차이를 사전, 3 회 관리 후, 6 회 관리 후 에 측정하여 반복측정 분산분석을 실시하였다(Table 3). 결과를 살 펴보면 목 부위 림프드레나지 후 관리 횟수에 따라 턱각도 수치(평

Table 2. Verification of homogeneity of the study population

\begin{tabular}{|c|c|c|c|c|c|}
\hline Division & & M & $\mathrm{SD}$ & $t$ & $p$ \\
\hline \multirow{2}{*}{ Wrinkle } & $\operatorname{MLD}(\mathrm{N}=10)$ & 33.80 & 3.084 & \multirow{2}{*}{0.231} & \multirow{2}{*}{0.820} \\
\hline & $\operatorname{BLD}(N=10)$ & 34.20 & 4.517 & & \\
\hline \multirow{2}{*}{ Epidermal layer pigmentation } & $\operatorname{MLD}(\mathrm{N}=10)$ & 11.70 & 3.093 & \multirow{2}{*}{-0.639} & \multirow{2}{*}{0.531} \\
\hline & $\operatorname{BLD}(\mathrm{N}=10)$ & 11.00 & 1.563 & & \\
\hline \multirow{2}{*}{ Skin tone } & $\operatorname{MLD}(\mathrm{N}=10)$ & 64.90 & 2.846 & \multirow{2}{*}{1.443} & \multirow{2}{*}{0.166} \\
\hline & $\operatorname{BLD}(\mathrm{N}=10)$ & 66.40 & 1.647 & & \\
\hline \multirow{2}{*}{ Jaw angle } & $\operatorname{MLD}(\mathrm{N}=10)$ & 45.77 & 2.797 & \multirow{2}{*}{0.588} & \multirow{2}{*}{0.564} \\
\hline & $\operatorname{BLD}(\mathrm{N}=10)$ & 46.55 & 3.127 & & \\
\hline \multirow{2}{*}{ Neck circumference } & $\operatorname{MLD}(\mathrm{N}=10)$ & 320.90 & 9.608 & \multirow{2}{*}{-0.021} & \multirow{2}{*}{0.983} \\
\hline & $\operatorname{BLD}(\mathrm{N}=10)$ & 320.80 & 11.163 & & \\
\hline \multirow{2}{*}{ Chin circumference } & $\operatorname{MLD}(N=10)$ & 264.10 & 15.941 & \multirow{2}{*}{-0.135} & \multirow{2}{*}{0.894} \\
\hline & $\operatorname{BLD}(\mathrm{N}=10)$ & 263.00 & 20.183 & & \\
\hline
\end{tabular}

M, mean; SD, standard deviation; BLD, bamboo lymph drainage; MLD, manual lymph drainage.

Table 3. Change in face edema

\begin{tabular}{lllll}
\hline \multirow{2}{*}{ Division } & & \multicolumn{3}{c}{ M \pm SD } \\
\cline { 3 - 5 } Jaw angle & & 0 Week & 3 Weeks later & 6 Weeks later \\
& BLD $(\mathrm{N}=10)$ & $46.55 \pm 2.79$ & $48.56 \pm 2.36$ & $49.80 \pm 3.45$ \\
Neck circumference & MLD $(\mathrm{N}=10)$ & $45.77 \pm 3.12$ & $47.57 \pm 1.87$ & $49.52 \pm 1.67$ \\
& $\mathrm{BLD}(\mathrm{N}=10)$ & $32.00 \pm 11.10$ & $31.40 \pm 11.90$ & $31.00 \pm 13.30$ \\
Chin circumference & $\mathrm{MLD}(\mathrm{N}=10)$ & $32.00 \pm 9.60$ & $32.10 \pm 14.30$ & $31.20 \pm 14.30$ \\
& $\mathrm{BLD}(\mathrm{N}=10)$ & $26.30 \pm 20.10$ & $26.00 \pm 19.30$ & $25.70 \pm 19.00$ \\
\hline
\end{tabular}

$\mathrm{M} \pm \mathrm{SD}$, mean \pm standard deviation; BLD, bamboo lymph drainage; MLD, manual lymph drainage.

Table 4. Repetitive measurement of face-related item distributed analysis results

\begin{tabular}{|c|c|c|c|c|c|c|}
\hline Division & & SS & df & MS & $F$ & $p$ \\
\hline \multirow{3}{*}{ Jaw angle } & Group & 7.004 & 1 & 7.004 & 0.477 & 0.499 \\
\hline & Time & 122.820 & 1.305 & 93.268 & 20.346 & $0.000^{* * *}$ \\
\hline & Time*Group & 1.330 & 1.305 & 1.010 & 0.220 & 0.710 \\
\hline \multirow{3}{*}{ Neck circumference } & Group & 135.000 & 1 & 135.000 & 0.345 & 0.564 \\
\hline & Time & 1011.433 & 1.305 & 775.060 & 12.064 & $0.001^{* *}$ \\
\hline & Time*Group & 128.100 & 1.305 & 98.163 & 1.528 & 0.235 \\
\hline \multirow{3}{*}{ Chin circumference } & Group & 26.667 & 1 & 26.667 & 0.029 & 0.867 \\
\hline & Time & 265.633 & 1.156 & 229.830 & 54.293 & $0.000^{* * *}$ \\
\hline & Time*Group & 1.633 & 1.156 & 1.413 & 0.334 & 0.601 \\
\hline
\end{tabular}

SS, square sum; df, degree of freedom; MS, mean square; ${ }^{* *} p<0.01 ;{ }^{* * *} p<0.001$. 
균값)는 높아졌으며, $\mathrm{BLD}$ 군은 턱각도의 수치가 사전 46.55에서 6 회 후 49.80로 증가하였고, MLD군은 사전 45.77에서 6회 후 49.52 로 증가하여 $\mathrm{BLD}$ 군이 턱각도 수치는 더 높아졌으나 통계적으로 유 의하지는 않았다. 목 부위 림프드레나지 후 목둘레 수치는 낮아졌으 며 $\mathrm{BLD}$ 군은 목둘레의 수치가 사전 32.0 에서 6회 후 31.0 으로 감소 하였고 $\mathrm{MLD}$ 군은 사전 32.0 에서 6 회 후 31.2 감소하여 $\mathrm{BLD}$ 군이 목 둘레수치가 더 낮아졌으나 통계적으로 유의하지는 않았다. 목 부위 림프드레나지 후 턱둘레 수치는 낮아졌으며, BLD군은 턱둘레의 수 치가 사전 26.3에서 6 회 관리 후 25.7 로 감소하였고 $\mathrm{MLD}$ 군은 사전 26.4 에서 6 회 후 25.9 로 감소하여 $\mathrm{BLD}$ 군이 턱둘레 수치가 더 낮아 졌으나 통계적으로 유의하지는 않았다(Table 3).

관리방법에 따라 턱각도 $(F=0.477, p>0.05)$, 목둘레 $(F=0.345$, $p>0.05)$, 턱둘레 $(F=0.029 p>0.05)$ 의 차이가 있는지를 알아본 결과
통계적으로 유의한 차이가 없는 것으로 나타났다. 그러나 측정시기 에 따른 턱각도 $(F=20.346, p<0.001)$, 목둘레 $(F=12.064, p<0.01)$, 턱둘레 $(F=54.293, p<0.001)$, 는 통계적으로 유의한 차이가 있는 것 으로 나타났으며, 측정시기와 집단 간의 상호작용효과는 모두 통계 적으로 유의한 차이가 없는 것으로 나타났다(Table 4).

부종개선과 관련된 선행연구를 살펴본 결과 Lee \& Ryu (2012), $\operatorname{Min} \& \operatorname{Kim}$ (2010)은 안면과 목 전면, 측면 위주의 림프드레나지를 통해 안면미용 성형수술 후 부종이 유의하게 감소하였고, MTS (미 세다륜침)으로 인위적 안면부종을 일으킨 후 안면과 목 전면 위주로 림프드레나지를 실시한 결과 안면의 부종과 통증이 유의하게 감소 하였다고 하였다. 이상의 결과에서 림프드레나지가 안면의 부종 개 선에 효과가 있음을 알 수 있고, 주로 안면이나 목의 전면과 측면을 관리한 선행연구와 달리 본 연구를 통해 뇌 림프시스템의 원리를 반

Table 5. Change in the facial skin condition

\begin{tabular}{|c|c|c|c|c|}
\hline \multirow{2}{*}{ Division } & & \multicolumn{3}{|c|}{$\mathrm{M} \pm \mathrm{SD}$} \\
\hline & & O Week & 3 Weeks later & 6 Weeks later \\
\hline \multirow{2}{*}{ Wrinkles } & $\operatorname{BLD}(\mathrm{N}=10)$ & $34.2 \pm 4.51$ & $29.9 \pm 4.65$ & $26.9 \pm 4.38$ \\
\hline & $\operatorname{MLD}(\mathrm{N}=10)$ & $33.8 \pm 3.08$ & $31.7 \pm 2.98$ & $29.9 \pm 3.38$ \\
\hline \multirow{2}{*}{ Epidermal layer pigment } & BLD $(N=10)$ & $11.0 \pm 1.56$ & $9.50 \pm 1.78$ & $8.50 \pm 1.84$ \\
\hline & $\operatorname{MLD}(\mathrm{N}=10)$ & $11.7 \pm 3.09$ & $10.7 \pm 2.98$ & $9.60 \pm 3.09$ \\
\hline \multirow{2}{*}{ Skin tone } & $\operatorname{BLD}(\mathrm{N}=10)$ & $66.4 \pm 1.64$ & $63.8 \pm 1.13$ & $62.5 \pm 1.78$ \\
\hline & $\operatorname{MLD}(\mathrm{N}=10)$ & $64.9 \pm 2.84$ & $64.4 \pm 2.83$ & $63.3 \pm 2.26$ \\
\hline
\end{tabular}

$\mathrm{M} \pm \mathrm{SD}$, mean \pm standard deviation; $\mathrm{BLD}$, bamboo lymph drainage; MLD, manual lymph drainage.

Table 6. Repeated measurement dispersion analysis results of facial skin condition item

\begin{tabular}{|c|c|c|c|c|c|c|}
\hline Division & & SS & df & MS & $F$ & $p$ \\
\hline \multirow{3}{*}{ Wrinkles } & Group & 32.267 & 1 & 32.267 & 0.770 & 0.392 \\
\hline & Time & 315.733 & 1.584 & 199.332 & 86.283 & $0.000^{* * *}$ \\
\hline & Time ${ }^{\star}$ Group & 29.733 & 1.584 & 18.772 & 8.126 & $0.003^{* *}$ \\
\hline \multirow{3}{*}{$\begin{array}{l}\text { Epidermal layer } \\
\text { pigment }\end{array}$} & Group & 15.000 & 1 & 15.000 & 0.835 & 0.373 \\
\hline & Time & 53.033 & 1.482 & 35.776 & 92.981 & 0.000 \\
\hline & Time*Group & 0.700 & 1.482 & 0.472 & 1.227 & 0.298 \\
\hline \multirow{3}{*}{ Skin tone } & Group & 0.017 & 1 & 0.017 & 0.001 & 0.971 \\
\hline & Time & 76.033 & 1.764 & 43.113 & 45.020 & $0.000^{* * *}$ \\
\hline & Time* Group & 16.233 & 1.764 & 9.205 & 9.612 & $0.001^{* *}$ \\
\hline
\end{tabular}

SS, square sum; df, degree of freedom; MS, mean square; ${ }^{* *} p<0.01 ;{ }^{* * *} p<0.001$.

Table 7. Subjective evaluation of the subjects after management

\begin{tabular}{|c|c|c|c|c|}
\hline Division & Group & $\mathrm{M} \pm \mathrm{SD}$ & $t$ & $p$ \\
\hline \multirow{2}{*}{$\begin{array}{l}\text { Comfortable part of } \\
\text { management }\end{array}$} & BLD & $4.40 \pm 0.51$ & \multirow{2}{*}{-1.11} & \multirow{2}{*}{0.27} \\
\hline & MLD & $4.70 \pm 0.67$ & & \\
\hline \multirow{2}{*}{$\begin{array}{l}\text { Helps improve facial } \\
\text { swelling }\end{array}$} & BLD & $4.30 \pm 0.67$ & \multirow{2}{*}{-1.52} & \multirow{2}{*}{0.14} \\
\hline & MLD & $4.70 \pm 0.48$ & & \\
\hline \multirow{2}{*}{$\begin{array}{l}\text { Helps improve skin } \\
\text { complexion }\end{array}$} & BLD & $4.20 \pm 0.78$ & \multirow{2}{*}{-1.34} & \multirow{2}{*}{0.19} \\
\hline & MLD & $4.60 \pm 0.51$ & & \\
\hline \multirow{2}{*}{$\begin{array}{l}\text { Satisfaction with } \\
\text { management in general }\end{array}$} & BLD & $4.50 \pm 0.52$ & \multirow{2}{*}{-2.05} & \multirow{2}{*}{0.05} \\
\hline & MLD & $4.90 \pm 0.31$ & & \\
\hline
\end{tabular}

$\mathrm{M} \pm \mathrm{SD}$, mean \pm standard deviation; 5 point scale; $\mathrm{BLD}$, bamboo lymph drainage; MLD, manual lymph drainage. 
영한 목 후면 림프드레나지의 경우에도 안면 부종에 효과가 있음을 입증하였다. 일반적으로 성형수술 후 환자는 수술부위에 대한 감염 이나 멍, 붓기, 통증에 대한 부담이 심리적으로 크고 실제 의료기관 에서 성형수술 후 감염예방을 위해 수술 부위에 직접적인 접촉이나 자극을 금기시하고 있어 고객이 성형 후 관리에 대한 관심은 높지만 실제 관리행동을 하는 데는 부담을 가질 수 있다는 점을 고려해야 된다. 따라서 이 연구의 결과는 비압박식 뱀부 림프드레나지가 성형 수술 후 감염과 수술 부위의 직접적인 접촉에 대한 부담을 덜고 부 종관리에 효과를 얻을 수 있음을 시사한다.

\section{2. 안면 피부상태의 변화}

사전, 3 회 관리 후, 6 회 관리 후 주름, 표피층 색소, 피부 톤을 측 정하여 반복측정 분산분석을 실시한 결과(Table 5) 목 부위 림프드 레나지 후 관리 횟수에 따라 주름 수치는 낮아져, 관리 전후 $\mathrm{BLD}$ 군 은 주름의 수치가 34.2 에서 6 회 관리 후 26.9 로 감소하였고 MLD군 은 33.8 에서 6 회 관리 후 29.9 로 감소하였으나 통계적으로 유의하 지 않았다. 관리 횟수에 따라 표피층 색소 수치는 낮아졌으며, $\mathrm{BLD}$ 군은 표피층 색소의 수치가 11.0 에서 6 회 관리 후 8.50 으로 낮아졌 고 MLD군은 11.7 에서 6 회 관리 후 9.60 으로 낮아졌으나 통계적으 로 유의하지 않았다. 관리 횟수에 따라 피부 톤 수치는 낮아졌으며, $\mathrm{BLD}$ 군은 피부 톤의 수치가 사전 66.4 에서 6 회 관리 후 62.5 로 감 소하였고, MLD군은 사전 64.9 에서 6회 관리 수 63.3으로 감소하여 $\mathrm{BLD}$ 군이 피부 톤 수치가 더 낮아졌으나 통계적으로 유의하지 않았 다.

관리 방법에 따라 안면 주름 $(F=0.770, p>0.05)$, 표피층 색소 $(F=0.835, p>0.05)$, 피부 톤 $(F=0.001, p>0.05)$ 에 차이가 있는지 를 알아본 결과 통계적으로 유의한 차이가 없는 것으로 나타났다. 그러나 측정시기에 따른 차이를 살펴본 결과 안면 주름 $(F=86.283$, $p\langle 0.001)$, 표피층 색소 $(F=92.981, p<0.001)$, 피부 톤 $(F=45.020$, $p\langle 0.001)$ 은 통계적으로 유의한 것으로 나타났으며, 측정시기와 집 단 간의 상호작용효과는 안면 주름 $(F=8.126, p<0.01)$, 피부 톤 $(F=9.612, p<0.01)$ 에서 통계적으로 유의한 차이가 있는 것으로 나 타났다. 그러나 표피층 색소 $(F=1.227, p\langle 0.05)$ 는 통계적으로 유의 한 차이가 없는 것으로 나타났다(Table 6).

림프드레나지의 안면 피부개선과 관련된 선행연구에서 $\mathrm{Min} \&$ $\operatorname{Kim}$ (2010)은 불안한 심리상태가 자율신경계활동을 증가시킴으로 생리적변화를 초래하여 생리계, 내분비계를 반응하여 코티솔이 선 택적으로 반응하여 급성 스트레스 상황을 반영한다 하였고, Lee \& Ryu (2012)는 림프드레나지가 코티솔 감소로 스트레스 관리에 효과 적이라고 하였으며, Choi \& Kim (2018)은 등 마사지가 목 피부 멜 라닌 변화량에 긍정적인 결과를 나타낸다 하였고, Kim et al. (2019) 는 연령별 얼굴 피부 노화 인식도 관계성 연구에서 주름, 기미, 피 부톤, 이중턱 처짐, 모공 크기 등에서 노화 정도와 연령대가 비례적 관계가 나타남을 알게 되었다. Kim \& Kang (2012)은 좌우 목운동
을 통해 혈류개선과 안면 피부, 안면 주름이 $25 \%$ 감소했다는 결과 에서 목 부위의 관리를 통한 혈액순환 개선과 스트레스 감소가 안면 의 주름에 효과적이라는 것을 알 수 있다. 또한 Kaplan (1995)은 일 상 업무의 집중과 피로로부터 자연스럽게 회복할 수 있는 적합한 매 력적 환경(자연과 연관된)에서 심리적 육체적으로 벗어난 느낌을 갖 게 되면 스트레스 완화 및 건강상태에 긍정적 작용이 나타난다고 하 였다. 본 연구에서 대상자는 심리적 육체적으로 안정된 누운 자세로 관리를 받았고 림프드레나지를 통해 뇌척수액 흐름을 원활하게 하 여 안면 주름과 피부 톤이 개선된 것으로 생각해볼 수 있다.

\section{3. 대상자의 주관적 평가 차이}

목 부위 림프드레나지에 대한 대상자의 주관적 평가에서 집단 간 유의한 차이는 나타나지 않았다. 뱀부 림프드레나지에 대한 평가는 리커트 5 점 척도로 평균이 최소 4.40 에서 최대 4.70 으로 나타나 만 족도가 매우 높은 것으로 분석되었다(Table 7).

\section{Conclusion}

본 연구는 뱀부를 활용한 목 부위 림프드레나지를 실시 후 안면 부종 및 피부 상태변화를 알아보고 피부관리 프로그램으로 뱀부 림 프드레나지 활용에 대한 기초자료를 제공하고자 하였다. 실험결과 에 따른 결론은 다음과 같다.

첫째, 뱀부 림프드레나지와 수기 림프드레나지에 따른 안면부종 상태변화를 파악한 결과 턱각도는 사전과 비교하여 3 회 후, 6 회 후 모두 유의하게 증가하고 턱둘레, 목둘레는 유의하게 감소하였다. 따 라서 뱀부 림프드레나지는 목 부위 관리를 통해 안면과 목 부위의 부종에 개선 효과가 있으므로 안면 미용성형 후, 여드름 관리, 안면 순환과 안면축소 관리를 위해 목 부위 집중관리 프로그램을 접목해 볼 수 있으며 뱀부 림프드레나지는 부위 관리를 통한 안면부종 개선 에 시너지 효과를 줄 수 있을 것이다.

둘째, 뱀부 림프드레나지와 수기 림프드레나지에 따른 안면 피 부상태 변화를 파악한 결과 안면 주름은 사전과 비교하여 3 회 관리 후 현저히 낮아졌고 6 회 관리 후에도 점진적으로 낮아져 모두 유의 한 결과를 보였고 표피층 색소, 피부 톤도 사전과 비교하여 3 회 관리 후, 6 회 관리 후 모두 유의하게 감소하였다. 그러므로 안면 피부관 리 및 메디컬 시술 후 예민 피부, 여드름 피부, 노화 피부, 스트레스 로 저하된 피부 톤 등의 피부 상태 개선 프로그램으로 목 부위 뱀부 림프드레나지를 실시하여 긍정적인 효과를 도울 수 있을 것으로 기 대된다.

셋째, 뱀부 림프드레나지와 수기 림프드레나지에 따른 안면 부종 및 피부 상태변화를 파악한 결과 두 집단 간에 차이는 없었고 두 관 리 모두 안면 부종 및 피부 상태가 개선되었다. 뱀부를 활용한 림프 드레나지는 넓은 면적에 작용하여 여러 개의 근육을 동시에 관리할 
수 있어 관리사의 기술에 크게 구애받지 않고 용이하게 관리할 수 있는 장점이 있다. 따라서 피부관리 현장에서 관리사의 경력 및 기 술정도에 따른 관리효과의 차이를 보완 할 수 있는 방안으로 뱀부관 리를 권장해 볼 수 있으며, 장시간 관리에 의한 관리사의 육체적 피 로도를 줄일 수 있는 방안으로 뱀부 관리를 제안해 볼 수 있다.

넷째, 뱀부 림프드레나지 관리 후 대상자들의 주관적 평가 결과 관리 부위의 편해짐, 붓기 및 안색 개선, 전반적인 만족도 항목에서 평균이 최소 4.40 부터 최대 4.70 (5점 척도)로서 피험자의 만족도가 매우 높게 나타나 뱀부를 활용한 피부 관리 시장의 확대 및 뱀부 프 로그램의 보급을 추진해 볼 가치가 있다. 또한 본 연구는 5 년 이상 경력의 숙련된 한 명의 연구자가 관리를 실시하였는데 차후 관리자 의 경력별 뱀부테라피 효과 차이와 연구대상자의 부종 정도, 목 부 위 통증정도에 따른 효과 차이 등을 연구해 볼 수 있을 것이다.

This work is part of the Mi Young Lee's M.Sc. thesis at the Changshin University, Changwon-si, Korea

\section{Author's contribution}

MYL did research design, performed experiments, data collection and analysis, and wrote overall papers, and YKO supervised project. All authors read and approved the final manuscript.

\section{Author details}

Mi Young Lee (Graduate student), Department of Cosmetology, Changshin University, 262 Palyongro, MasanHoewongu, Changwon, Gyeongsangnam-do 51352, Korea; Yun Kyoung Oh (Professor), Department of Cosmetology, Changshin University, 262 Palyongro, MasanHoewongu, Changwon, Gyeongsangnam-do 51352, Korea,

\section{References}

Choi YE, Kim YJ. Effects of soybean diet and back massage on the neck skim of middle-aged women. Asian Journal of Beauty and Cosmetology, 16: 533-544, 2018.

Eum HK, Moon DH, Sim EK. Effects of lymph massage on lower body edema among women in pregnancy. Journal of the Korean Society of Beauty and Art, 18: 55-64, 2017.

Han YS. A Study of the effect on facial treatment according to direction and tempo of the MLD (manual lymph drainage) stationary circles technique. Asian Journal of Beauty and Cosmetology, 3: 119-124, 2005.

Iliff JJ, Wang M, Liao Y, Plogg BA, Peng W, Gundersen GA, Benveniste H, Vates GE, Deane R, Goldman SA, et al. A paravascular pathway facilitates CSF fow through the brain parenchyma and the clearance of interstitial solutes including amyloid $\beta$. Science Translational Medicine, 4:147, 2012.

Kaplan S. The restorative benefits of nature: towards an integrative framework. Journal of Environmental Psychology, 15: 169-182, 1995.

Kim MS, Kang SM. The effect analysis on middle-aged women's neck wrinkles improvement of shaking neck exercise and collagen diet. Journal of the Korean Society of Cosmetology, 18: 806-815, 2012.

Kim KB, Kim JY, An S, Min E, Bae S. Evaluation of the perception and clinical characteristics of facial skin aging according to age-group among Korean women. Asian Journal of Beauty and Cosmetology, 17: 387-396, 2019.

Kim SJ, Ro HL. Effects of manual lymph drainage on the edema and quality of life in lymphedema patients of maintenance phase. The Journal of the Korean Society of Physical therapy, 21: 89-96, 2009.

Kim SJ, Sim JM, Park YD. Effects of aromatherapy massage on edema reduction in the treatment of lymphedema. Physical Therapy Korea, 14: 1-8, 2007.

Kwon TI, Heo HS. Appearance satisfaction and self-esteem according to the actual situation of eyelash beauty. Asian Journal of Beauty and Cosmetology, 17: 295-306, 2019.

Lee EW, Ryu HW. The calming effects of manual lymph drainage on the facial flushing and edema symptoms induced by the microneedle therapy system stimulus. Asian Journal of Beauty and Cosmetology, 10: 637-643, 2012.

Leem S, Chang J, Kim Y, Shin JG, Song HJ, Lee SG, Yoo S, Lee J, Myoung J, Park SG, et al. Repeated measurements of facial skin characteristics using the Janus-III measurement system. Skin Research and Technology, 26: 362-368, 2020.

Lee OD. Bamboo therapy (Third Hand). Korea Bamboo Therapy Association, Seoul, pp12-102, 2016.

Lee SI. Contemporary beauty expressions from the 
perspective of Lao-tzu's philosophy: focusing on cosmetics advertisement. Journal of Fashion Business, 18: 15-24, 2014.

Min JY, Kim HJ. The effect of manual lymph drainage on the reduction of stress and edema after facial aesthetic plastic surgery. Asian Journal of Beauty and Cosmetology, 8: 143-156, 2010.

Pyun ES, Yun CS. The effect of MLD and aroma MLD on stress hormone, and psychological factors of menopausal woman. Journal of Korean Society of Beauty and Art, 15: 67-81. 2014.

Sim JM. The effect of manual lymphatic drainage on the change of eletrocardiogram. Asian Journal of Beauty and Cosmetology, 4: 211-224, 2006.

Son SH, Sin SH, Lee JN. Korea bamboo therapy. Guminsa, Seoul, pp70-113, 2019.

Song JH. The effect of Hinoki cypress (Chamaecyparis obtusa) essential oil and manual lymph drainage on mental health in 30's carrier women. Korean Society of Cosmetics and Cosmetology, 9: 309-321, 2019.
Osorio S. Bamboo massage: the past blends with the present as these stalks enable penetrating maneuvers, saving therapists hands in the process. Massage and Bodywork, 23: 84-91, 2008.

Wang LH, Wang ZL, Chen WY, Chen MJ, Xu GY. The glymphatic system: concept, function and research progresses. Sheng Li Xue Bao, 70: 52-60, 2018.

Wittlinger $\mathrm{G}$, Wittlinger $\mathrm{H}$. Textbook of Dr. Vodder's manual lymph drainage (7th ed.). Thieme, New York, pp23-95, 2003.

Xie L, Kang H, Xu Q, Chen MJ, Liao Y, Thiyagarajan M, O'Donnell J, Christensen D, Nicholson C, lliff J, et al. Sleep drives metabolite clearance from the adult brain. Science, 342: 373-377, 2013.

Yoon IS, Choi HJ. Effects of lymphatic drainage on electroencephalogram and electrocardiogram. Asian Journal of Beauty and Cosmetology, 10: 597-603, 2012. 


\section{국문초록}

\section{목 부위 뱀부 림프드레나지가 안면부종 및 피부상태에 미치는 영향}

이미영, 오윤경*

창신대학교 미용예술학과, 경상남도 창원시, 한국

목적: 목 부위에 뇌 림프시스템 원리를 반영한 뱀부 림프드레나지와 닥터보더식 수기 림프드레나지를 실시하여 안면부종 및 안면피 부상태의 변화를 비교 분석함으로써 그 효과를 검증하여 뱀부 림프드레나지 활용에 대한 기초자료를 제시하고자 한다. 방법: 대구 지역의 20 대 여대생을 선발하여 연구 참여 동의자 20 명을 대상으로 실험군은 뱀부를 사용하여 목 부위 림프드레나지를 30 분간 실 시하였고 대조군도 같은 방법으로 수기 림프드레나지를 하였으며 주 2 회, 3 주간 총 6 회 실시하였다. 결과: 첫째, 뱀부 림프드레나 지와 수기 림프드레나지에 따른 안면 부종상태 변화를 파악한 결과 3 회, 6 회 관리 후 턱각도는 유의하게 증가하였고, 턱둘레, 목둘 레는 유의하게 감소하였다. 둘째, 뱀부 림프드레나지와 수기 림프드레나지에 따른 안면 피부상태 변화를 파악한 결과 안면주름, 표 피층 색소, 피부 톤은 3 회 관리 후 현저히 낮아졌고 6 회 관리 후에도 점진적으로 낮아져 시기별 유의한 차이가 나타났다. 셋째, 뱀부 림프드레나지와 수기 림프드레나지의 관리 전·후의 변화에서 두 집단 모두 안면부종 및 안면피부상태가 집단 간의 차이는 통계적으 로 유의하게 나타나지 않았다. 넷째, 관리 후 대상자들의 주관적 만족도가 조사 결과 전반적인 만족도가 매우 높게 나타났다. 결론: 목 부위 뱀부 림프드레나지는 피부상태 개선에 효과를 얻을 수 있다는 근거를 제시하였다. 관리사의 기술과 경력에 따른 차이와 신 체적 피로도를 줄일수 있는 방안으로 뱀부 림프드레나지를 제안해 볼 수 있다.

핵심어: 뱀부림프드레나지, 매뉴얼림프드레나지, 뱀부, 림프드레나지, 목 부위 부종

\section{참고문헌}

권태일, 허혜순. 속눈썹 미용실테에 따른 외모만족도와 자아존중감. 아시안뷰티화장품학술지, 17: 295-305, 2019.

김기쁨, 김지예, 안성관, 민은설, 배송희. 한국 성인 여성의 연령별 얼굴 노화 정도에 대한 인식과 임상학적 특성에 관한 연 구. 아시안뷰티화장품학술지, 17: 387-396, 2019.

김민송, 강상모. 좌우 목운동 및 콜라겐 식이가 중년 여성의 목 주름 개선에 미치는 영향 분석. 한국미용학회지, 18: 806$815,2012$.

김성중, 노효련. 유지기 림프부종환자에서 MLD가 부종과 삶의 질에 미치는 영향. 대한물리치료학회지, 21: 89-96, 2009.

김성중, 심정묘, 박용덕. 아로마 마사지가 림프부종에 미치는 영향. 한국전문물리치료학회지, 14: 1-8, 2007.

민자영, 김형주. 엠엘디(MLD)가 안면성형수술 후 스트레스, 부종 감소에 미치는 영향. 아시안뷰티화장품학회지, 8: 143156, 2010.

손소희, 신숙희, 이재남. 한국형 뱀부테라피. 구민사, 서울, pp70-113, 2019.

송정희. 30 대 직장여성의 편백정유 림프드레니쥐가 정신 건강에 미치는 영향. 한국화장품미용학회지, 9: 309-321, 2019.

심정묘. 엠엘디(MLD)가 심전도에 미치는 영향. 아시안뷰티화장품학회지, 4: 211-224, 2006.

엄혜경, 문덕환, 심은경. 림프마사지가 임신중 산모들의 하체 부종에 미치는 효과. 한국인체미용예술학회지, 18: 55-64, 2017.

윤임실, 최현주. 안면 림프드레나쥐가 뇌파와 심전도에 미치는 영향. 아시안뷰티화장품학술지, 10: 597-603, 2012. 이수인. 현대 미인에 나타난 노자적 미학의 표현양상: 화장품 광고를 중심으로. 패션비지니스, 18: 15-24, 2014. 이오들. (테라피 역사상 최초! 지렛대원리를 이용한 제 3의 손) 뱀부테라피. 한국뱀부테라피협회, 서울, pp12-102, 2016. 
이은우. Microneedle Theerapy System (MTS)자극에 의해 유발된 얼굴 홍조와 부종에 대한 림프마사지의 완화효과. 아 시안뷰티화장품학술지, 10: 637-643, 2012.

편이숙, 윤천성. MLD와 Aroma MLD가 폐경기 여성의 스트레스 호르몬, 심리적 변인에 미치는 영향. 한국인체미용예술 학회지, 15: $67-81,2014$.

최영은, 김윤정. 청국장 식이와 등 마사지가 중년여성의 목 피부에 미치는 영향. 아시안뷰티화장품학술지, $16: 533-544$, 2018.

한영숙. MLD (manual lymphdrainage)의 stationary circles technique의 방향과 속도에 따른 안면관리 효과에 대한 연 구. 아시안뷰티화장품학술지, 3: 119-124, 2005. 


\section{中文摘要}

\section{竹颈淋巴引流对面部水肿和皮肤状况的影响}

李美英, 吳允京 ${ }^{*}$

昌信大学美容艺术学科, 庆尚南道昌原市, 韩国

目的：根据脑淋巴系统的原理进行竹淋巴引流，并在颈部区域进行医生边界型淋巴引流，并比较每种方法对面部 浮肿和皮肤状况的影响。方法: 在大邱招收20多岁的女大学生; 从这20个中选择。实验组受试者在颈部颈部用竹 子进行了 30 分钟的淋巴引流，而对照组则以相同的方式每周两次进行了3周的手淋巴引流。结果：首先，由于根 据BLD和MLD改变的面部水肿状态, 3次和6次后下领角明显增加, 下领和颈部的周长明显减少。其次, 了解根 据BLD和MLD引起的面部皮肤状况的变化后, 与治疗前相比, 治疗3次后面部皱纹, 表皮色素沉着和肤色明显减 少, 而治疗6次后逐渐减少。第三, 两组的BLD和MLD所显示的面部水肿和皮肤状况变化无差异。第四, 对受试 者的主观评价表明, 管理受试者的满意度很高。结论: 竹淋巴引流术可以减轻治疗师的身体疲劳, 同时有效地管 理治疗师之间的差异，这取决于个人的技能和经验。

关键词: 竹淋巴引流, 手动淋巴引流, 竹子, 淋巴引流, 颈部和水肿 